\title{
Exponential-phase expression of spvA of the Salmonella typhimurium virulence plasmid: induction in intracellular salts medium and intracellularly in mice and cultured mammalian cells
}

\author{
Julie A. Wilson, $\uparrow$ Thomas J. Doyle and Paul A. Gulig \\ Author for correspondence: Paul A. Gulig. Tel: +1 352392 0050. Fax: +1 3523923133. \\ e-mail: gulig@college.med.ufl.edu
}

Department of Molecular Genetics and Microbiology, University of Florida College of Medicine, Gainesville, FL 32610-0266, USA

\begin{abstract}
The spv genes of Salmonella typhimurium and other non-typhoidal Salmonella serovars are essential for efficient systemic infection beyond the intestines in orally inoculated mice as a model for enteric fever. These virulence genes are not significantly expressed by salmonellae during exponential growth in $\mathbf{L}$ broth but are induced when the bacteria enter the stationary phase of growth. Using RNase protection analysis to directly measure spvA mRNA from the virulence plasmid of $S$. typhimurium, we found that spvA was maximally induced in an SpvR- and RpoS-dependent manner during exponential growth in Intracellular Salts Medium, which mimics the intracellular environment of mammalian cells. A cloned spvA-lacZ operon fusion in S. typhimurium was induced intracellularly in peritoneal cells of mice, correlating in vivo intracellular gene expression with intracellular function of the spv genes in infected mice. spvA was also induced intracellularly in vitro within both Henle407 intestinal epithelial cells and J774.A1 macrophage-like cells when the bacteria were replicating with exponential kinetics. Prevention of invasion of salmonellae with cytochalasin D inhibited spvA induction within tissue culture cells, indicating that salmonellae must be internalized for spvA to be induced. The spvA-lacZ fusion was not induced by salmonellae in extracellular fluid of the peritoneal cavity or in serum. Since induction of the spv genes occurs intracellularly during exponential growth of salmonellae, cessation of growth may not be the most relevant inducing signal for spv gene expression.
\end{abstract}

Keywords: Salmonella typhimurium, virulence, regulation, expression

\section{INTRODUCTION}

Salmonella typhimurium and other non-typhoidal Salmonella serovars are invasive pathogens that normally cause gastroenteritis in the healthy population. However, in immunocompromised individuals, such as those with AIDS (Wilkins \& Roberts, 1988), certain serovars of Salmonella can cause systemic disease. The nontyphoidal Salmonella serovars with potential to cause systemic disease possess genetically related high-

\footnotetext{
Abbreviations: ISM, Intracellular Salts Medium; i.p., intraperitoneally. †Present address: United States Army Medical Research Institute of Infectious Diseases, Frederick, MD 21702-5011, USA.
}

molecular-mass virulence plasmids (Gulig et al., 1993) and a high percentage of invasive clinical isolates, as opposed to non-invasive and environmental isolates, of $S$. typhimurium and $S$. enteritidis contain a virulence plasmid (Montenegro et al., 1991; Fierer et al., 1992). The virulence plasmid is also necessary for lethal systemic infection in orally inoculated mice as a model of enteric fever (Gulig et al., 1993). Gulig \& Doyle (1993) used a temperature-sensitive genetic marker to show that the virulence plasmid increases systemic infection of $S$. typhimurium by increasing the growth rate of salmonellae within host cells of mice. However, the exact mechanism by which the virulence plasmid causes increased intracellular growth and the host cell(s) associated with plasmid-mediated intracellular growth are unknown. 
Five genes, $s p v R A B C D$, encoded on a highly conserved $8 \mathrm{~kb}$ region common to the virulence plasmids of several Salmonella serovars are sufficient to replace the entire virulence plasmid for mediating systemic infection (Gulig et al., 1993, 1992) and increased growth rate in mice (Gulig \& Doyle, 1993). spvR encodes a positive activator that increases the transcription of the other $s p v$ genes (Caldwell \& Gulig, 1991; Fang et al., 1991; Matsui et al., 1991; Taira et al., 1991; Coynault et al., 1992), which are encoded as an operon (Fang et al., 1991; Matsui et al., 1993; Krause et al., 1992). spvABCD are believed to encode the effector functions for plasmidmediated virulence. However, their DNA sequences and deduced amino acid sequences have not aided in the elucidation of their function. Studies have suggested that SpvB and/or SpvA can negatively regulate $s p v R$ (Abe $e t$ al., 1994; Spink et al., 1994). However, in our studies, a deletion of $s p v B$ on the virulence plasmid of $S$. typhimurium had no effect on the steady-state levels of $s p v R$ mRNA and a deletion of $s p v A$ supported a role for SpvA as a negative regulator of $s p \nu R$ only under specific growth conditions (J. A. Wilson \& P. A. Gulig, unpublished).

The $s p v$ genes are poorly expressed by salmonellae growing exponentially in rich media but are induced in the stationary phase of growth (Fang et al., 1991; Coynault et al., 1992; Taira et al., 1995) in a manner which is dependent on the RpoS alternative sigma factor for RNA polymerase (Fang et al., 1992; Norel et al., 1992; Chen et al., 1995; Heiskanen et al., 1994; Kowarz et al., 1994). Expression of the $s p v$ genes from different Salmonella serotypes has also been found to be differentially regulated in response to alterations in the growth medium. For instance, environmental factors such as iron limitation, $\mathrm{pH}$, heat shock and glucose levels have been implicated in regulating the expression of $S p v$ proteins expressed from the $S$. dublin virulence plasmid (Valone et al., 1993). In addition, it has been reported that $s p v-l a c Z$ fusions on the virulence plasmid of $S$. typhimurium can be negatively regulated by catabolite repression (O'Byrne \& Dorman, 1994a) and the histone-like protein, H-NS (O'Byrne \& Dorman, 1994b).

The majority of the research aimed at elucidating the genetic regulation of the $s p v$ genes has focused on examining post-exponential growth regulation (Guiney et al., 1995; Abe et al., 1994; O’Byrne \& Dorman, 1994a; Spink et al., 1994; Valone et al., 1993; Coynault et al., 1992; Krause et al., 1992; Fang et al., 1991; Taira et al., 1995). However, Gulig \& Curtiss (1987) demonstrated that $S$. typhimurium replicates with exponential growth kinetics in the spleens of infected mice during the first week of infection when the $s p v$ phenotype of increased intracellular growth is evident. In this study, we examined $s p v$ gene expression to determine if cessation of growth was necessary for induction. We report that $s p \nu A$ was induced in the exponential phase of growth when S. typhimurium was grown in minimal medium, with the greatest amount of induction occurring in a medium designed to mimic the intracellular environment of animal cells. Transcription of $s p v A$ was also induced intracellularly in vitro in mammalian cell culture and in vivo in peritoneal cells of intraperitoneally (i.p.) inoculated mice. A preliminary report of these results has been presented (Rogers et al., 1995).

\section{METHODS}

Bacterial strains and growth conditions. Virulence plasmidcontaining S. typhimurium SR-11 strains $\chi 3181$ and $\chi^{3306}$ (gyrA1816) and isogenic virulence plasmid-cured $\chi 3337$ (gyrA1816) have been described previously (Gulig \& Curtiss, 1987). Escherichia coli $\chi 6060$ was used as a host strain for construction of pGTR319 and pGTR326, which were used for RNase protection analysis. $\chi 6060$ is E. coli CC118 (Gutierrez et al., 1987) with the $\mathrm{F}^{\prime}$ from JM105 (Yanisch-Perron et al., 1985) containing a $\operatorname{Tn} 5$ insertion $\left(\mathrm{F}^{\prime}\right.$ traD36 proA ${ }^{+}$proB ${ }^{+}$lacl $^{\mathrm{q}}$ lacZ $\Delta \mathrm{M} 15 \mathrm{Tn} 5)$. The $r p o S:: \mathrm{pRR} 10$ mutation of $S$. typhimurium SF1005 (kindly provided by Ferric Fang, University of Colorado; Fang et al., 1992) was transduced into S. typhimurium $\chi 3181$ by P22HTint-mediated generalized transduction (Schmeiger, 1972). Transductants were selected for ampicillin resistance and screened for the $\mathrm{RpoS}^{-}$phenotype of decreased catalase production when mixed with hydrogen peroxide and the $r p o S$ derivative of $\chi 3181$ was named UF064. UF088 contains a deletion of the ScaI-DraI fragment of $s p v R$ on the virulence plasmid of S. typhimurium $\chi 3306$. This SpvR mutant was constructed using the allelic exchange suicide vector pCVD442 (Donnenberg \& Kaper, 1991).

Bacteria were grown at $37^{\circ} \mathrm{C}$ in $\mathrm{LB}$ or on L agar (Lennox, 1955), M9 minimal medium (Maniatis et al., 1982) or Intracellular Salts Medium (ISM), pH 7.4 (Headley \& Payne, 1990 ) supplemented with antibiotics at the following concentrations $\left(\mu \mathrm{g} \mathrm{ml}^{-1}\right)$ as appropriate: ampicillin, 100 ; chloramphenicol, 30; nalidixic acid, 25 ; tetracycline, $12 \cdot 5$.

Construction of reporter plasmids. All DNA manipulations were performed by standard genetic and molecular techniques (Ausubel et al., 1993; Maniatis et al., 1982). lacZ operon fusion plasmids were constructed as described by Caldwell \& Gulig (1991) and are depicted in Fig. 1(a). pGTR090 was constructed from pGTR101, which consists of the $4.2 \mathrm{~kb}$ EcoRI fragment encoding spvABC cloned into pACYC184 (Caldwell \& Gulig, 1991). The lacZ, cat cartridge on a bluntended BamHI fragment from pSGMU32 (Errington, 1986) was inserted into the blunt-ended SstI sites within $s p v A$ and $s p v B$ of pGTR101. pGTR090 therefore contains an $s p v A-l a c Z$ operon fusion in the place of the SstI fragment encoding the $3^{\prime}$ end of $s p v A$ and the $5^{\prime}$ end of $s p v B$. pGTR311 was constructed from pYA442, which consists of sequences from the $\mathrm{NruI}$ site upstream of $s p v R$ to within $s p v B$ (Caldwell \& Gulig, 1991). The lacZ,cat cartridge from pSGMU32 on an Smal-HindIII fragment was inserted into pYA442 which was digested with SstI (blunt-ended) and HindIII. This yielded $s p v R$ followed by an $s p v A-l a c Z$ operon fusion and did not contain any spv sequences downstream of the fusion. pGTR075 (Caldwell \& Gulig, 1991) contains a tet-lacZ operon fusion and consists of the lacZ,cat cassette of pSGMU38 (Errington, 1986) inserted in the opposite orientation to $s p v R$.

Isolation of total bacterial RNA. Static overnight cultures of S. typhimurium strains were diluted to $1 \times 10^{6}$ c.f.u. $\mathrm{m}^{-1}$ into fresh medium and incubated further. Exponential-phase cultures were harvested at an $\mathrm{OD}_{600}$ of $0.3-0.4$ and postexponential/stationary cultures were harvested $4-5 \mathrm{~h}$ after salmonellae ceased exponential growth. Total bacterial RNA from $5 \times 10^{10}$ to $1 \times 10^{11}$ c.f.u. was isolated using the step- 


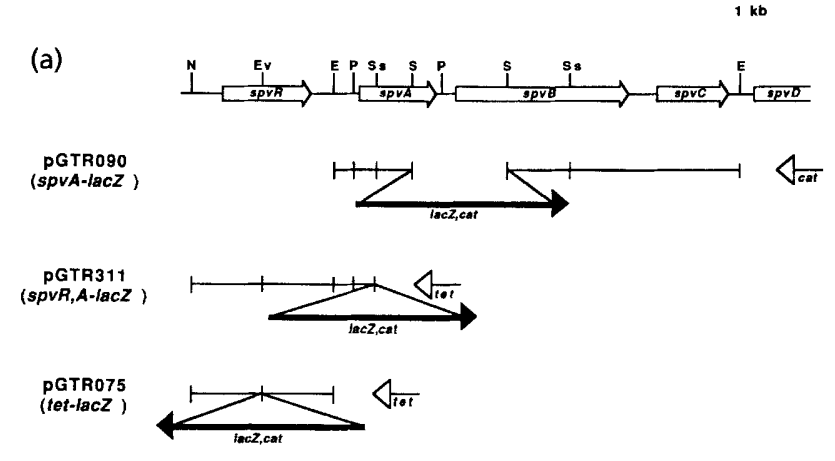

(b)

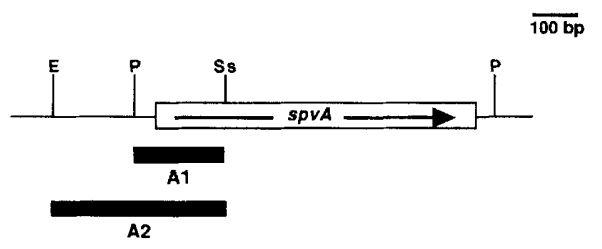

Fig. 1. Physical maps of the lacz operon fusions used in this study (a) and the probes used to detect spvA mRNA using the ribonuclease protection assay (b). The five $s p v$ virulence genes of $S$. typhimurium and the direction of transcription for each gene are depicted as open arrows. The cloned spv sequences of each of the operon-fusion-containing plasmids are shown. The orientation and insert sites of the lacZ, cat cassette are indicated by the solid arrows (not drawn to scale). The pACYC184encoded tetracycline resistance gene (tet) or chloramphenicol resistance gene (cat) into which the spv genes were cloned are also shown. The bold lines in (b) depict the regions of the ${ }^{32} \mathrm{p}$ labelled antisense RNA probes that are complementary to spvA mRNA. E, EcoRI; Ev, EcoRV; N, Nrul; P, Pstl; S, Sstl; Ss, Sstll.

gradient $\mathrm{CsCl}$ density centrifugation method of Deretic et al. (1987), except that the lysed cell suspensions containing $\mathrm{CsCl}$ were centrifuged at room temperature for exponential cultures or at $15{ }^{\circ} \mathrm{C}$ for post-exponential cultures. RNA was resuspended in water treated with diethyl pyrocarbonate (Sigma) and any residual DNA was removed with RNase-free DNase I (Boehringer Mannheim). RNA was extracted once with water-saturated phenol, once with phenol/chloroform/ isoamyl alcohol and then ethanol-precipitated (Ausubel et al., 1993). The RNA pellets were resuspended in diethyl pyrocarbonate-treated water and RNA concentrations were determined spectrophotometrically by measuring $A_{260}$. Relative quantification of RNA was confirmed by examining rRNA bands on ethidium bromide-stained agarose-formaldehyde gels (Ausubel et al., 1993).

Primer extension analysis. The $5^{\prime}$ transcriptional start sites of the spvA mRNA were mapped by primer extension analysis as described by Maniatis et al. (1982) using a ${ }^{32} \mathrm{P}$-labelled $30 \mathrm{nt}$ oligomer designed to hybridize to the $5^{\prime}$ end of the spvA mRNA (PG58) and $100 \mu \mathrm{g}$ of RNA isolated from S. typhimurium $\times 3181$ growing at post-exponential/stationary phase in LB. Primer extension products were resolved on a $7 \mathrm{M}$ urea, $5 \%\langle\mathrm{w} / \mathrm{v}\rangle$ polyacrylamide sequencing gel, exposed to Kodak $\mathrm{X}$-Omat AR film and visualized by autoradiography. The size of the extension product was estimated by comparison to a sequencing ladder generated with the same oligonucleotide primer.
Quantification of SpVA mRNA by RNase protection analysis. RNase protection analysis was performed as described by Ausubel et al. (1993) using ${ }^{32} \mathrm{P}$-labelled antisense RNA probes (Fig. 1b) generated by T7 run-off transcription of EcoRIdigested pGTR319 or pGTR326 using an RNA transcription kit (Stratagene) and $\left[\alpha^{32} \mathrm{P}\right] \mathrm{CTP} \quad\left[3000 \mathrm{Ci} \mathrm{mmol}^{-1}\right.$ (110 TBq mmol ${ }^{-1}$ ); Amersham]. pGTR319 contains the $5^{\prime}$ Pst I-SstII fragment of $s p v A$ and pGTR326 contains the $5^{\prime}$ EcoRI-SstII fragment of $s p v A$ cloned into pBluescript KS (Stratagene). EcoRI digestion of the DNA templates created the 3' ends of the antisense RNA transcripts. One hundred micrograms of either total bacterial RNA (for quantification of $\mathrm{mRNA}$ ) or yeast tRNA (Boehringer Mannheim) as a negative control was hybridized with $5 \times 10^{5}$ c.p.m. of antisense probe RNA. Non-hybridizing RNA was digested with RNase A (Sigma) and RNase T1 (Life Technologies), and the hybridized RNA products were resolved on a $7 \mathrm{M}$ urea, $5 \%$ polyacrylamide sequencing gel. The amount of residual radiolabelled antisense probe RNA protected by $s p v A \mathrm{mRNA}$ was quantified on a PhosphorImager (Molecular Dynamics) at the University of Florida Interdisciplinary Center for Biotechnology Research DNA Synthesis Facility.

Cell culture infection for analysis of $s p v$ gene expression. All cell culture reagents were obtained from Life Technologies. The Henle-407 human intestinal epithelial cell line (Intestine 407, ATCC CCL 6) was obtained from the American Type Culture Collection, Rockville, MD, USA, and was maintained in Basal Medium Eagle with Earle's salts (BME) supplemented with $10 \%(\mathrm{v} / \mathrm{v})$ heat-inactivated foetal calf serum, $100 \mathrm{U}$ penicillin ml-1 and $100 \mu \mathrm{g}$ streptomycin $\mathrm{ml}^{-1}$ in an atmosphere of $5 \%(\mathrm{v} / \mathrm{v}) \mathrm{CO}_{2}$. The J774.A1 murine macrophage-like cell line was a gift from Frederick Southwick (Department of Medicine, University of Florida College of Medicine) and was maintained in Dulbecco's Modified Eagle Medium (DMEM) containing $5 \%$ heat-inactivated foetal calf serum, $100 \mathrm{U}$ penicillin $\mathrm{ml}^{-1}$ and $100 \mu \mathrm{g}$ streptomycin $\mathrm{ml}^{-1}$. For gene expression and replication assays, cell cultures were seeded at a density of $2.5 \times 10^{5}$ Henle-407 cells per well or $1 \times 10^{6}$ J774.A1 cells per well in six-well tissue culture plates (Costar) $36 \mathrm{~h}$ prior to bacterial infection, resulting in approximately $70 \%$ confluency at the time of infection.

Infection of cell cultures. Cell monolayers were rinsed once with Hanks' Balanced Salt Solution (HBSS) and incubated at $37^{\circ} \mathrm{C}$ for $1 \mathrm{~h}$ with antibiotic-free culture medium to remove residual antibiotics before bacterial infection. Exponentialphase salmonellae were obtained by diluting static overnight broth cultures 100 -fold into pre-warmed LB $\left(37^{\circ} \mathrm{C}\right)$ and shaking until the $\mathrm{OD}_{600}$ reached $0 \cdot 3-0 \cdot 4$. Bacterial cells were centrifuged at $10000 \mathrm{~g}$ for $10 \mathrm{~min}$ at room temperature and resuspended in pre-warmed cell culture medium containing foetal calf serum. Salmonellae were added to the monolayers at an m.o.i. of 10 bacteria per host cell. Infected cell cultures were incubated for $1 \mathrm{~h}$ at $37^{\circ} \mathrm{C}$ in $5 \% \mathrm{CO}_{2}$ to enable adherence and invasion by salmonellae to occur. Infected monolayers were gently washed three times with $2.5 \mathrm{ml}$ HBSS to remove non-adherent bacteria and were incubated for $1 \mathrm{~h}$ in fresh medium containing $100 \mu \mathrm{g}$ gentamicin $\mathrm{ml}^{-1}$ to kill extracellular bacteria. We found that prolonged incubation in $100 \mu \mathrm{g}$ gentamicin $\mathrm{ml}^{-1}$ decreased intracellular replication of salmonellae. Therefore, after $1 \mathrm{~h}$ incubation in $100 \mu \mathrm{g}$ gentamicin $\mathrm{ml}^{-1}$, the monolayers were washed two times with HBSS and incubated in fresh medium containing $10 \mu \mathrm{g}$ gentamicin $\mathrm{ml}^{-1}$ for the remainder of the experiment. At various times after infection, the monolayers were rinsed twice with PBS containing $0 \cdot 1 \%$ gelatin (BSG) to remove extracellular bacteria and media components which contribute to background $A_{\mathbf{4 2 0}}$. 
Monolayers were lysed by vigorous aspiration with $1 \mathrm{ml}$ PBS containing $0.1 \%(\mathrm{w} / \mathrm{v})$ sodium deoxycholate, $\mathrm{pH} 8$. The intracellular c.f.u. of salmonellae was enumerated by diluting and plating using triplicate sampling of each infected well. The remaining lysate was processed in a modification of the Miller assay for measuring $\beta$-galactosidase activity as described below. To control for basal expression of lac $Z$ fusions, salmonellae were incubated in cell culture medium alone for the same length of time that extracellular infection was allowed to proceed $(1 \mathrm{~h})$. These samples were centrifuged and resuspended in PBS containing $0.1 \%$ deoxycholate, then processed exactly as described for wells containing infected culture cells.

Inhibition of invasion with cytochalasin D. To inhibit invasion of salmonellae into host cells, Henle-407 cells were treated with BME containing $5 \mu \mathrm{g}$ cytochalasin $\mathrm{D} \mathrm{m}^{-1}$ (Sigma) for $45 \mathrm{~min}$ before infection. Infections were performed as indicated above, except that all solutions contained $5 \mu \mathrm{g}$ cytochalasin $\mathrm{D} \mathrm{ml} \mathrm{ml}^{-1}$. Gentamicin was also omitted from wells used for measuring gene expression from cytochalasin D-treated monolayers, since gentamicin killed greater than $99 \%$ of the resulting adherent, extracellular salmonellae.

Opsonization with rat serum. Salmonellae $\left(1.1 \times 10^{7}\right.$ c.f.u. $\left.\mathrm{ml}^{-1}\right)$ were incubated in $10 \%(\mathrm{v} / \mathrm{v})$ normal rat serum in DMEM at $37^{\circ} \mathrm{C}$ for 30 min prior to infection of J774.A1 cells. Normal rat serum was also present throughout the first hour of infection of J774.A1 cells.

Infection of mice and measurement of spv gene expression in vivo. To examine the expression of $s p v A$ from S. typhimurium infecting host cells in mice, we developed a procedure for delivering salmonellae to host cells, selecting for intracellular growth, recovering the infected host cells and measuring intracellular gene expression. In the place of using pGTR090 as the spvA-lacZ fusion plasmid, we used pGTR311, which contains the spvA-lacZ fusion in cis to $s p \nu R$. Since $s p v R$ is provided in cis, pGTR311 was placed into virulence plasmid-cured $\chi 3337$. This construct produces approximately tenfold higher levels of $\beta$-galactosidase activity than pGTR090 during intracellular infection in cell culture.

Static overnight cultures of $S$. typhimurium strains $\chi 3337$ (pGTR311), $\chi 3337$ (pGTR075) and $\chi 3337$ grown at $37^{\circ} \mathrm{C}$ in LB supplemented with the appropriate antibiotics were diluted 1:100 into fresh LB without antibiotics and shaken at $37^{\circ} \mathrm{C}$ until the cell density reached an $\mathrm{OD}_{600}$ of $0 \cdot 3-0 \cdot 4$. Bacterial cells were centrifuged at $8000 \mathrm{~g}$ for $10 \mathrm{~min}$ at room temperature and the bacterial pellets were resuspended in BSG. Sets of three female, 7-10-week-old, specific pathogenfree $\mathrm{BALB} / \mathrm{c}$ mice (Charles River) were injected i.p. with $1 \times 10^{7}$ c.f.u. of salmonellae in $0 \cdot 1 \mathrm{ml} \mathrm{BSG}$.

Isolation of intracellular salmonellae. Three hours after injection of salmonellae, sets of mice infected with $\chi 3337$ (pGTR311), $\chi 3337$ (pGTR075) or $\chi 3337$ were injected i.p. with $150 \mu \mathrm{g}$ gentamicin to kill extracellular bacteria. One hour later, mice were sacrificed by $\mathrm{CO}_{2}$ asphyxiation and the peritoneal cavities were lavaged three times with a total of $12 \mathrm{ml}$ ice-cold BSG. Lavages of the three mice were pooled. To examine the effectiveness of the i.p. gentamicin treatment in killing extracellular bacteria, a $2 \mathrm{ml}$ sample of the peritoneal lavage was passed through a $5 \mu \mathrm{m}$ filter (Millipore) and the number of extracellular, non-cell-associated salmonellae was enumerated. Injection of gentamicin at $1 \mathrm{~h}$ pre-harvest killed between 90 and $99 \%$ of the extracellular bacteria. The remaining lavage fluid was centrifuged at $800 \mathrm{~g}$ to pellet host cells containing intracellular bacteria. The pellet was re- suspended in $2.5 \mathrm{ml}$ PBS containing $0.1 \%$ sodium deoxycholate, $\mathrm{pH} 8$, which lysed host cells and released intracellular bacteria. The intracellular c.f.u. of salmonellae was enumerated by diluting and plating on selective media. The remaining lysate was processed in a modification of the Miller assay for measuring $\beta$-galactosidase activity (see below).

Isolation of extracellular salmonellae. Four hours after injection of S. typhimurium $\chi 3337$ (pGTR311), a set of mice not injected with gentamicin was sacrificed by $\mathrm{CO}_{2}$ asphyxiation and peritoneal cavities were lavaged as described above. Extracellular salmonellae were obtained by filtering the pooled lavage fluid through a $5 \mu \mathrm{m}$ filter which removed host cells and permitted the extracellular bacteria to pass through the filter. The filtrate was then centrifuged at $8000 \mathrm{~g}$ for $10 \mathrm{~min}$ to pellet the bacteria and the salmonellae were resuspended in $2.5 \mathrm{ml}$ PBS containing $0 \cdot 1 \%$ sodium deoxycholate, $\mathrm{pH} 8$. The extracellular c.f.u. of salmonellae was enumerated by diluting and plating on selective media. The remaining lysate was processed in a modification of the Miller assay for measuring $\beta$ galactosidase activity (see below).

\section{Assay of $\beta$-galactosidase activity}

Miller assays. Measurement of $\beta$-galactosidase activity from salmonellae grown in culture medium was performed as described by Miller (1972), except that the cell debris was removed by centrifugation prior to determination of $A_{420}$. Enzymic activity normalized to bacterial cell number is presented as Miller units. Each experiment was performed at least three times with triplicate reactions each and values are reported as the mean of triplicate reactions \pm SD.

$\beta$-Galactosidase activity from infected tissue cell cultures and peritoneal lavages. The $\beta$-galactosidase assay was performed as described by Miller (1972) with the following modifications. All solutions were at $\mathrm{pH} 8$, since mammalian $\beta$-galactosidase is inactive at this $\mathrm{pH}$ (Pollack et al., 1986), and the $\mathrm{OD}_{600}$ of cell culture lysates was calculated using the conversion factor $1 \times 10^{8}$ c.f.u. $\mathrm{ml}^{-1}=0.18 \mathrm{OD}_{600}$. Data are presented as 'cell-associated' units of $\beta$-galactosidase activity $=$ $\left[A_{420} /\left(t \nu \mathrm{OD}_{600}\right)\right] \times 10^{4}$, where $t$ is the reaction time (min) and $\nu$ is the volume of cell lysate $(\mathrm{ml})$. The values reported are the mean $\pm S D$ of either triplicate wells of cultured cells or triplicate samples of pooled peritoneal lavage. In all experiments, the values obtained for $\mathrm{Lac}^{-}$wild-type $\chi 3181$ or plasmid-cured $\chi 3337$ were subtracted from the other samples. To measure intracellular gene expression relative to expression in culture medium, units of $\beta$-galactosidase activity of salmonellae from infected cells were divided by the units of activity from bacteria incubated in cell culture medium alone (-fold induction). Because the lacZ operon fusions were encoded on cloned virulence plasmid sequences, we also measured $\beta$-galactosidase activity from the control tet-lacZ fusion in the same vector (pGTR075) to control for nonspecific effects on the vector (e.g. change in copy number).

\section{RESULTS}

\section{spvA is expressed during exponential growth in minimal medium}

Several researchers have demonstrated that the $s p v$ virulence plasmid genes are poorly expressed by salmonellae growing exponentially in rich media, but can be induced in the post-exponential phase of bacterial growth (Guiney et al., 1995; Abe et al., 1994; O’Byrne \& Dorman, 1994a ; Spink et al., 1994; Valone et al., 1993; 
(a)

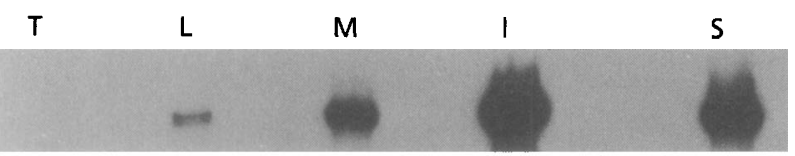

(b)

$\frac{\text { Exponential }}{M} \frac{\text { Post-exponential }}{M} \quad \frac{1}{M}$

Fig. 2. RNase protection analysis of spvA mRNA from wild-type $S$. typhimurium $\chi 3306$ in various growth conditions. The ${ }^{32} \mathrm{P}$ labelled antisense RNA probe $A 1$ shown in Fig. 1 (b) was hybridized with $100 \mu \mathrm{g}$ total bacterial RNA isolated from $\chi 3306$ or $100 \mu \mathrm{g}$ yeast tRNA (lane T) as a negative control. mRNA from salmonellae isolated in exponential-phase growth in either LB (lane L), M9 minimal medium (lane M), or ISM (lane I), or in post-exponential/stationary-phase growth in LB (lane S). (b) mRNA isolated from salmonellae in exponential-phase and post-exponential-phase growth in M9 medium (lanes $M$ ) or in ISM (lanes I). RNA was resolved on a $5 \%(\mathrm{w} / \mathrm{v})$ polyacrylamide/7 $\mathrm{M}$ urea sequencing gel and was visualized by autoradiography. This experiment was repeated at least three times with similar results.

Coynault et al., 1992; Krause et al., 1992; Fang et al., 1991; Taira et al., 1995). Since salmonellae may not cease replicating in infected animal hosts, we asked if the $s p v$ genes could also be induced when salmonellae are growing exponentially. We measured $s p v A$ mRNA from the virulence plasmid of wild-type $S$. typhimurium growing exponentially in the nutrient-rich medium LB and in ISM, a minimal medium designed to mimic the intracellular environment of animal cells (Headley \& Payne, 1990). As a positive control, expression of spvA was also quantified from salmonellae grown to post-exponential/stationary phase in LB. We focused these studies on the regulation of $s p v A$ because it is the first gene of the $s p v$ operon and is transcriptionally regulated in the same manner as the downstream $s p v$ genes (Krause et al., 1992; Matsui et al., 1993) (J. A. Wilson \& P. A. Gulig, unpublished).

Equivalent amounts of RNA were analysed by RNase protection analysis using a ${ }^{32} \mathrm{P}$-labelled antisense RNA probe that was complementary to the $5^{\prime}$ end of the $s p v A$ mRNA (Fig. 1b, probe A1). No protected band corresponding to $s p v A$ mRNA was detected from virulence plasmid-cured S. typhimurium (data not shown) or from control samples containing yeast tRNA in the place of bacterial RNA (Fig. 2a, lane T). Virulence plasmidcontaining salmonellae growing at exponential phase in LB produced a low basal level of spvA mRNA (Fig. 2a, lane L). When the bacteria were grown to post- exponential phase in LB, $s p v A$ was induced 27 -fold (Fig. $2 \mathrm{a}$, lane $\mathrm{S}$ ) relative to basal expression in LB. The greatest amount of induction $(65$-fold relative to basal expression in LB) occurred when the salmonellae were growing exponentially in ISM (Fig. 2a, lane I). This result demonstrated that $s p v A$ induction was not dependent on a cessation of bacterial growth and was consistent with the hypothesis that $s p v$ gene expression is regulated in response to an environmental signal(s) encountered within host cells. However, since the doubling time of salmonellae is longer in ISM than in LB $(1.2 \mathrm{~h}$ versus $0.4 \mathrm{~h}$ per generation, respectively), it is possible that the bacteria were inducing $s p v A$ in response to the bacterial growth rate rather than the nutrient composition of ISM.

To determine if the slower growth rate in ISM was responsible for the induction of $s p v A, s p v A$ mRNA was also measured from wild-type $S$. typhimurium growing exponentially in M9 minimal medium. S. typhimurium has a similar generation time in M9 medium and ISM. Therefore, if growth rate is itself the regulating factor in $s p v A$ induction, the level of $s p v A$ mRNA should be the same in M9 and in ISM. Although spvA was induced when the salmonellae were growing exponentially in M9 medium (7·3-fold over basal expression in LB; Fig. $2 \mathrm{a}$, lane $\mathrm{M}$ ), the amount of $s p v A$ mRNA detected was still ninefold lower in M9 than in ISM, indicating that factors other than the bacterial growth rate were responsible for the increased expression of $s p v A$ during exponential growth in ISM relative to LB and M9 media.

To ascertain whether the minimal medium (ISM and M9) and post-exponential-phase inductions were additive events, the expression of $s p v A$ was measured from wild-type $S$. typhimurium grown to exponential and post-exponential/stationary phase in either ISM or M9 minimal medium. When the bacteria were grown to post-exponential phase in M9 medium, spvA mRNA increased twofold relative to exponential growth in $\mathrm{M} 9$ (Fig. 2b, lanes M). In contrast to salmonellae grown in LB or M9 minimal medium, the steady-state level of $s p v A$ from salmonellae grown to post-exponential phase in ISM was less than the level measured from salmonellae growing exponentially in ISM (Fig. 2b, lanes I). This result shows that the regulatory elements controlling the expression of the $s p v$ genes for ISM and stationary-phase inductions are not additive.

It was possible that the lack of further induction of $s p v$ expression in post-exponential-phase growth in ISM was specific to the $s p v$ genes or alternatively that the physiological state of salmonellae in post-exponential growth in ISM impeded expression of other stationaryphase-induced genes. We therefore examined the expression of two starvation-induced genes, stiA and stiC, throughout growth in ISM. Similar to the $s p v$ genes, $s t i A$ and $s t i C$ are both positively regulated by the RpoS alternative $\sigma$ factor during phosphate, carbon and nitrogen starvation (O'Neal et al., 1994; M. P. Spector $\&$ P. A. Gulig, unpublished data). stiA and $s t i C$ MudJ(lacZ) fusions were induced during exponential 
growth in ISM relative to exponential growth in $\mathrm{LB}$, as was observed for $s p v A$ (data not shown). The level of expression by these sti genes in ISM was estimated to be three- to fourfold higher than what is typically observed in other carbon-, phosphate- or nitrogen-limiting nutrient media (M. P. Spector, J. A. Wilson \& P. A. Gulig, unpublished data). The expression of stiA during stationary-phase growth in ISM was unchanged compared with exponential growth in ISM. In contrast, stiC was further induced fourfold during stationary-phase growth relative to exponential-phase growth in ISM (data not shown). Since stiA and $s t i C$ are regulated in similar manners during phosphate, nitrogen and carbon starvation, there is no obvious explanation for the different patterns of expression between these genes during stationary-phase growth in ISM. The results obtained with stiA and stiC demonstrate that the reduced levels of $s p v$ gene expression during stationaryphase growth in ISM are not due to a global decrease in gene expression, but are due to the specific regulation of the $s p v$ genes in relation to the biochemical composition of ISM.

On examining the differential induction of the $s p v$ genes in LB, M9 and ISM, we also considered the possibility that the salmonellae were responding to the osmolarity of the growth medium and not to a specific ion or nutrient, since O'Byrne \& Dorman (1994b) reported that osmolarity could affect $s p v$ gene expression. The osmolality of LB was measured at 251 mosmol, M9 minimal medium was 218 mosmol and ISM was 403 mosmol. The facts that the $s p v$ genes are maximally expressed in ISM and the osmolality of ISM is greater than the osmolality of LB and M9 are consistent with the possibility that osmolality is involved in $s p v$ gene regulation in these media. However, because $M 9$ and LB have similar osmolalities and yet caused differential expression of the $s p v$ genes, it is unlikely that osmolality alone regulates the expression of the $s p v$ genes in these growth media. In addition, when the expression of an spvA-lacZ fusion was measured from $\chi 3181$ (pGTR090) growing in low-osmolarity $\mathrm{K}$ Medium (77 mosmol) or in $\mathrm{K}$ Medium containing $0.3 \mathrm{M} \mathrm{NaCl}(643 \mathrm{mosmol})$, there was no difference in the expression of $s p v A$ (data not shown). Taken together, these results indicate that the difference in expression of the $s p v$ genes in LB, M9 and ISM is not primarily the result of differences in the osmolarity of the media.

\section{Analysis of genetic elements involved in the differential expression of spvA}

Since we identified two different conditions for induction of $s p v A$, we wanted to determine if these regulatory events could be explained by differential promoter usage at $s p v A$. Using primer extension analysis, Krause et al. (1992), Matsui et al. (1993) and Kowarz et al. (1994) previously identified two $5^{\prime}$ ends for the $s p v A$ message. We similarly identified two $5^{\prime}$ ends of the S. typhimurium $s p v A$ mRNA by primer extension analysis at approximately -72 and -99 bases upstream of the $s p v A$

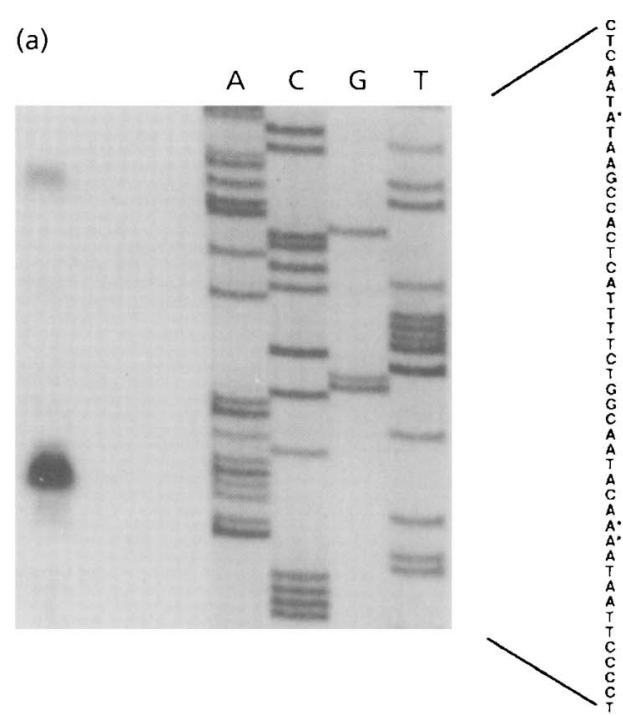

(b)
S

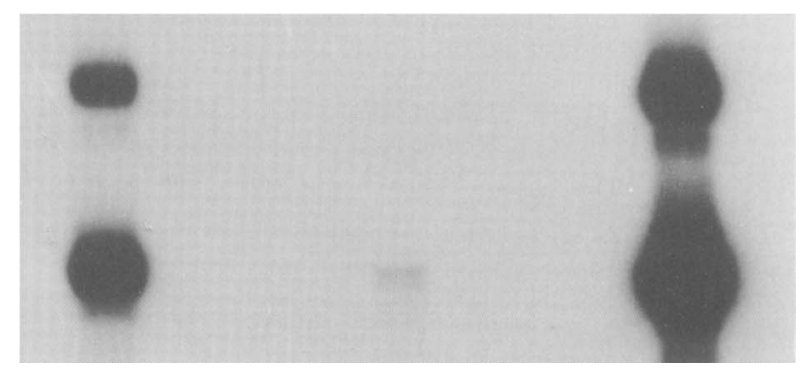

Fig. 3. Analysis of the $5^{\prime}$ ends of spvA mRNA transcripts by primer extension (a) or RNase protection (b). (a) Identification of two $5^{\prime}$ ends for spvA mRNA. Primer extension analysis was performed on $100 \mu \mathrm{g}$ RNA isolated from $\chi^{3181}$ during postexponential/stationary-phase growth in LB. Sequencing reactions generated using the same primer are shown, and the asterisks indicate the DNA sequence corresponding to the initiation sites upstream of the initiator ATG codon. (b) RNase protection analysis demonstrating identical $5^{\prime}$ ends of spvA mRNA under non-induced and induced conditions in vitro. The upper band in lane $L$ was visible on a longer exposure of the film (not shown). The ${ }^{32} \mathrm{P}$-labelled antisense RNA probe $\mathrm{A} 2$ shown in Fig. 1(b) was hybridized with $100 \mu \mathrm{g}$ total bacterial RNA isolated from $\chi 3306 \mathrm{~S}$. typhimurium growing exponentially in either LB (lane L) or ISM (lane I), or post-exponentially in LB (lane S). RNA was resolved on a $5 \%(w / v)$ polyacrylamide/7 $M$ urea sequencing gel and was visualized by autoradiography. This experiment was repeated at least three times with similar results.

ATG start codon (Fig. 3a). We also identified these two $5^{\prime}$ ends using RNase protection analysis (Fig. $3 \mathrm{~b}$ ). The sizes of the protected fragments corresponding to the $5^{\prime}$ ends of the $s p v A$ mRNA were identical, regardless of the inducing condition examined, demonstrating that differences in the regulation of $s p v A$ in response to stationary-phase growth in LB or exponential growth in ISM are not due to differential promoter usage. $s p v A$ mRNA isolated from salmonellae growing exponentially in LB also contained both $5^{\prime}$ ends (the lighter upper 

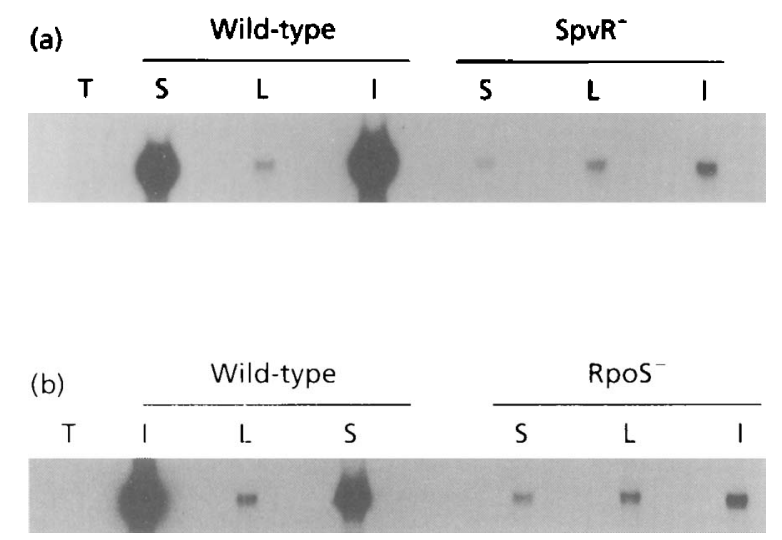

Fig. 4. RNase protection analysis of spvA mRNA from wild-type, SpvR $^{-}$(a) and RpoS $^{-}$(b) $S$. typhimurium in various growth conditions. The ${ }^{32} \mathrm{P}$-labelled antisense RNA probe A1 shown in Fig. 1(b) was hybridized with $100 \mu \mathrm{g}$ total bacterial RNA isolated from salmonellae growing exponentially in LB (lanes L) or ISM (lanes I), or post-exponentially in LB (lanes S). Yeast tRNA ( $100 \mu \mathrm{g}$; lane T) was used as a negative control. RNA was resolved on a $5 \%(w / v)$ polyacrylamide $7 \mathrm{M}$ urea sequencing gel and was visualized by autoradiography. This experiment was repeated at least three times with similar results.

band was visible on a longer exposure of the film), indicating that these start sites were not selectively utilized only under the inducing conditions. In addition, since the relative intensities of these two protected fragments to each other were not altered under these different growth conditions, both transcripts were similarly induced in stationary phase and in ISM.

It has been established that $s p v$ expression in stationary phase is dependent on the alternative $\sigma$ factor RpoS (Chen et al., 1995; Heiskanen et al., 1994; Kowarz et al., 1994; O'Neal et al., 1994; Fang et al., 1992; Norel et al., 1992) and SpvR (Fang et al., 1991; Coynault et al., 1992; Abe et al., 1994; Spink et al., 1994; Guiney et al., 1995; Taira et al., 1995). Having identified exponential-phase growth in ISM as a highly inducing condition for $s p v$ gene expression, we wanted to determine if regulation of $s p v A$ was mediated by different genetic elements between stationary-phase in LB and exponential-phase growth in ISM. To examine the relative roles of $S p v R$ and RpoS in ISM vs stationary-phase inductions of $s p v A$, we compared the levels of $s p v A$ mRNA from wild-type, SpvR ${ }^{-}$and $\mathrm{RpoS}^{-}$S. typhimurium during exponential growth in LB and ISM, and at stationary phase in LB (Fig. 4). Loss of either SpvR or RpoS did not affect the basal expression of $s p v A$ from salmonellae growing exponentially in LB (compare lanes L). The expression of $s p v A$ was greatly reduced during exponential growth in ISM (lanes I) and during postexponential growth in LB (lanes S) in both the SpvR ${ }^{-}$ and $\mathrm{RpoS}$ salmonellae compared with the corresponding growth conditions in the wild-type strain. Therefore, similar to post-exponential growth in LB, maximal induction of $s p v A$ during exponential growth in ISM was dependent on both RpoS and the virulence-plasmidencoded SpvR.

\section{Expression of spvA from lacZ operon fusions}

In the above experiments, RNase protection analysis was used to directly measure $s p v A$ expressed from the virulence plasmid of $S$. typhimurium. Since this assay does not lend itself to measuring $s p v A$ mRNA from the low numbers of salmonellae recovered from tissue culture cells, we used a lac $Z$ operon fusion to measure the intracellular expression of $s p v A$. pGTR090 contains a lacZ operon fusion in the SstI site of $s p v A$, but does not encode the essential positive regulatory factor, SpvR. We therefore placed pGTR090 into the wild-type, virulence-plasmid-containing strain $\chi 3181$, from which SpvR could be provided in trans. To determine if $s p v A$ of pGTR090 responded to the same inducing conditions as $s p \nu A$ mRNA from the native virulence plasmid, wildtype $S$. typhimurium containing pGTR090 was grown to exponential and post-exponential phases in LB, M9 and ISM. $\chi 3181$ (pGTR090) produced $4 \cdot 7 \pm 0 \cdot 2$ Miller units of activity during exponential growth in LB, $140 \pm 0.5$ Miller units in $\mathrm{M9}$ minimal medium and $370 \pm 3.5$ Miller units in ISM. When the minimal media inductions were divided by the increases observed for the control tet-lacZ fusion from pGTR075 ( $\leqslant 5 \cdot 7$-fold), spvA-lacZ from $S$. typhimurium $\chi 3181$ (pGTR090) was specifically induced 5.2-fold in M9 medium and 16-fold in ISM. In addition, when we measured expression of $s p v A$ from post-exponential-phase cultures of salmonellae, we detected $85 \pm 2.7$ Miller units in LB, $570 \pm 9 \cdot 6$ Miller units in $M 9$ medium and $340 \pm 2.9$ Miller units in ISM. When the post-exponential-phase inductions were divided by the small increases observed for the control tet-lacZ fusion $(\leqslant 1 \cdot 8$-fold), $s p v A$ was specifically induced tenfold during post-exponential-phase growth in LB and fourfold in M9 medium relative to exponential-phase cultures in the same media. Similar to what was observed from the analysis of $s p v A$ mRNA from the virulence plasmid (Fig. 2b), spvA from $\chi 3181$ (pGTR090) was not further induced during post-exponential growth in ISM relative to exponential-phase growth in ISM. Therefore, the induction of $s p v A$ was qualitatively the same regardless of whether $s p \nu A$ was measured as $\beta$-galactosidase activity from pGTR090 or as mRNA from the native virulence plasmid.

\section{spvA is induced intracellularly in both Henle-407 human intestinal epithelial cells and J774.A1 murine macrophage-like cells}

S. typhimurium and other virulence plasmid-containing Salmonella serovars are facultative intracellular pathogens that survive and replicate within a variety of host cells, including epithelial cells and phagocytic cells of the reticuloendothelial system (Finlay \& Falkow, 1989). However, since the cell type in which the $s p v$ phenotype of increased intracellular growth occurs is not known, we measured intracellular $s p v$ gene expression in representatives of both phagocytes and non-phagocytes.

To examine the intracellular expression of $s p v A$ in nonphagocytic cells, Henle-407 human intestinal epithelial cells were infected with wild-type S. typhimurium $\chi 3181$ 
Table 1. Expression of spvA in cultured mammalian cells

Henle-407 epithelial cells (a) or J774.A1 cells (b) were infected with wild-type S. typhimurium $\chi 3181$ containing the spvA-lacZ fusion plasmid pGTR090 either in the presence of gentamicin to measure intracellular gene expression or in the presence of cytochalasin D to measure expression from adherent, extracellular salmonellae at various times post-infection. This experiment was repeated at least three times with similar results. ND, Not determined

\begin{tabular}{|c|c|c|c|c|c|}
\hline & \multicolumn{5}{|c|}{ Cell-associated units of $\beta$-galactosidase activity \pm SD (-fold induction) ${ }^{*}$} \\
\hline & Culture medium & \multicolumn{4}{|c|}{ Length of intracellular infection } \\
\hline \multicolumn{6}{|l|}{ (a) } \\
\hline $\begin{array}{l}\text { - Gentamicin/ } \\
\text { + cytochalasin D }\end{array}$ & $14 \pm 0 \cdot 2$ & $17 \pm 2 \cdot 6(1 \cdot 2)$ & $16 \pm 0 \cdot 8(1 \cdot 1)$ & ND & ND \\
\hline \multicolumn{6}{|l|}{ (b) } \\
\hline $\begin{array}{l}\text { + Gentamicin/ } \\
\text { - cytochalasin D }\end{array}$ & $19 \pm 0 \cdot 3$ & $46 \pm 2 \cdot 8(2 \cdot 4)$ & $62 \pm 5 \cdot 8(3 \cdot 3)$ & $98 \pm 4 \cdot 0(5 \cdot 2)$ & $180 \pm 10(9 \cdot 5)$ \\
\hline
\end{tabular}

*-fold induction, expression associated with tissue culture cells/expression in cell culture medium.

containing either pGTR090 (spvA-lacZ) or pGTR075 (tet-lacZ). Intracellular expression from the operon fusions was measured $2,4,6$ and $8 \mathrm{~h}$ after infection of the monolayers and is expressed as cell-associated units of $\beta$-galactosidase. At $\mathrm{pH} 8$, the conversion of ONPG from uninfected Henle-407 cells or from Henle-407 cells infected with salmonellae lacking a lac $Z$ fusion construct was equal to the spontaneous hydrolysis of ONPG in deoxycholate lysis buffer alone, indicating that no significant $\beta$-galactosidase activity was present in the host cells. Expression of the $s p v A-l a c Z$ operon fusion was not induced in cell culture medium relative to LB. However, as soon as $2 \mathrm{~h}$ after infection of Henle- 407 cells, intracellular expression of $s p v A$ was induced 2.7fold relative to expression in cell culture medium and continued to increase up to 14 -fold at $8 \mathrm{~h}$ after infection (Table 1a). No induction was observed for the tet-lac $Z$ fusion (data not shown).

To verify that $s p v A$ was induced by the intracellular location of the salmonellae and not by contact of the bacteria with the cultured mammalian cells, we inhibited invasion of salmonellae into Henle- 407 cells with the microfilament inhibitor cytochalasin D. Cytochalasin D prevents only the uptake of salmonellae by the tissue culture cells; the bacteria are still able to adhere to the cell monolayer (Finlay \& Falkow, 1988). Inhibition of invasion suppressed the induction of $s p v A$ throughout the first $4 \mathrm{~h}$ of infection (Table 1a). By $6 \mathrm{~h}$ post-infection, the cytochalasin D-treated cells detached from the culture plates and could no longer be monitored. Again, there was no induction of the tet-lac $Z$ fusion under these conditions. Therefore, bacterial contact with the cultured cells was not sufficient to induce expression of $s p v A$.

To determine if the intracellular induction of $s p v A$ was specific to non-phagocytic cells, or if $s p v A$ was also induced in phagocytes, intracellular $s p v A$ expression was measured in J774.A1 murine macrophage-like cells (Table 1b). Similar to what was seen for the Henle- 407 cells, spvA was induced within $2 \mathrm{~h}$ after infection (2.4fold relative to tissue culture medium alone) and continued to increase up to $9 \cdot 5$-fold at $8 \mathrm{~h}$ after infection. Expression of the tet-lac $Z$ fusion was not induced in J774.A1 cells. Therefore, the intracellular induction of $s p v A$ occurred in both phagocytic and non-phagocytic cells, indicating that the salmonellae may be responding to an inducing signal that is common to the intracellular environments of both cell types.

\section{S. typhimurium is replicating with exponential kinetics when spvA is induced in either Henle-407 or J774.A1 cells}

We wanted to distinguish the possibilities that the intracellular induction of $s p v A$ in these tissue culture cells was due to a cessation of growth, i.e. an intracellular stationary phase, or an ISM-like condition of exponential-phase intracellular growth. We therefore measured the intracellular replication of salmonellae in both Henle-407 and J774.A1 cells (Fig. 5). At the time points when maximal induction of spvA occurred within these cells, the bacteria were replicating exponentially with a doubling time of approximately $2 \mathrm{~h}$. If a cessation of growth or a lag phase did occur, it was very brief and occurred early in the infection process when the induction of $s p v A$ was minimal.

\section{spvA is not expressed in serum}

The expression of $s p v A$ within mammalian cells is consistent with the $s p v$ genes being active within host cells to increase the intracellular replication rate (Gulig 


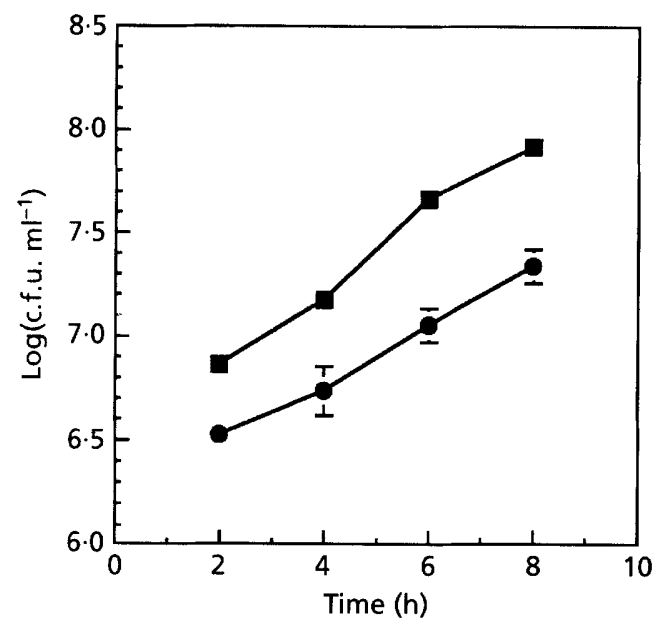

Fig. 5. Intracellular growth of wild-type S. typhimurium containing pGTR090 in Henle-407 intestinal epithelial cells (O) and J774.A1 macrophage-like cells ( $\boldsymbol{D})$, demonstrating that the salmonellae were replicating with exponential kinetics when spvA was induced. The values of the means $\pm S D$ of triplicate wells are shown. This experiment was performed at least three times with similar results.

\& Doyle, 1993). To determine if the $s p v$ genes are similarly induced in an extracellular environment, where we hypothesize that the genes are not involved with virulence, we examined spvA expression in vitro in a medium mimicking the nutrient conditions of the extracellular environment that salmonellae might encounter in an animal host. In these studies, wild-type $S$. typhimurium $\chi 3181$ containing the spvA-lacZ operon fusion on plasmid pGTR090 was diluted to a final concentration of $1 \times 10^{6}$ c.f.u. $\mathrm{ml}^{-1}$ in pre-warmed foetal calf serum. The bacteria were then incubated either as a standing culture at $37^{\circ} \mathrm{C}$ in an atmosphere of $5 \% \mathrm{CO}_{2}$ or as a shaking culture at $37^{\circ} \mathrm{C}$ in ambient atmosphere. Expression of $s p v A$ was measured from the $s p v A-l a c Z$ fusion construct using c.f.u. from plating converted to $\mathrm{OD}_{600}$. The amount of $\beta$-galactosidase activity from cultures grown to an $\mathrm{OD}_{600}$ of approximately 0.3 was low $\left(2 \cdot 9 \pm 0 \cdot 1\right.$ Miller units in $5 \% \mathrm{CO}_{2}$ and $3 \cdot 0 \pm 0 \cdot 1$ Miller units in the aerated culture) and did not increase as the cultures approached an $\mathrm{OD}_{600}$ of 1 . Therefore, $s p v A$ was not induced in a medium mimicking the extracellular environment of an animal host, where the genes are not involved with virulence.

\section{spvA is induced intracellularly in mice}

To examine if the intracellular induction of $s p v A$ also occurred in vivo in mice, we infected mice i.p. with S. typhimurium carrying an $s p v A-l a c Z$ fusion plasmid, pGTR311, which expressed higher levels of $\beta$-galactosidase than pGTR090, as described in Methods. Four hours after i.p. inoculation of mice with $\chi 3337$ (pGTR311), expression of spvA-lacZ from extracellular bacteria obtained by filtering the peritoneal lavage through a $5 \mu \mathrm{m}$ filter yielded an $A_{420}$ that was not significantly above background generated by $\chi 3337$ alone. This result is consistent with the lack of expression in foetal calf serum, an in vitro assay for the extracellular milieu. However, expression from gentamicin-resistant intracellular $\chi 3337$ (pGTR311) (16000 150 Miller units) was induced 70 -fold over expression from the LB-grown inoculum $(230 \pm 2$ Miller units). The control tet-lac $Z$ fusion from pGTR075 was not measurably induced in vivo. This experiment was repeated three times with similar results. To attempt to identify the relevant host cell(s) in which intracellular salmonellae induced expression of spvA-lacZ, mice were infected as described in Methods and cytospin preparations of peritoneal cells were examined using immunochemical staining of both salmonellae and host cells. Salmonellae were associated primarily with macrophages $\left(\mathrm{F} 4 / 80^{+}\right)$(McKnight et al., 1996) and granulocytes $\left(\mathrm{Gr}-1^{+}\right)$(Fleming et al., 1993) (data not shown). Since a variety of host cells was infected after i.p. inoculation, we could not determine in which cell type the induction of $s p v A$ occurred.

\section{Intracellular induction of the spv genes in tissue culture cells does not lead to an increase in the intracellular growth rate of virulence-plasmid- containing S. typhimurium}

Since we demonstrated that the $s p v$ virulence plasmid genes of $S$. typhimurium mediate systemic infection by increasing the growth rate of salmonellae within host cells (Gulig \& Doyle, 1993) and we showed here that the $s p v A$ operon is induced intracellularly within both phagocytic and non-phagocytic cells and in ISM, we reexamined the effect of the virulence plasmid on replication of S. typhimurium in cell culture. Although we and others (Gulig \& Curtiss, 1987; Riikonen et al., 1992) have examined this previously, our recent studies identified potential technical problems which could have obscured differential growth rates in cell culture. Specifically, the extended use of high levels of gentamicin $\left(100 \mu \mathrm{g} \mathrm{ml}^{-1}\right)$ inhibited recovery of intracellular bacteria and infection times over $12 \mathrm{~h}$ resulted in destruction of the monolayers. In addition, S. typhimurium was shown recently to induce apoptosis in cultured macrophages (Monack et al., 1996; Chen et al., 1996b).

When we measured the number of wild-type and virulence-plasmid-cured salmonellae from infected Henle-407 and J774.A1 cells throughout the first $12 \mathrm{~h}$ post-infection, the generation times for the two strains were approximately $2.5 \mathrm{~h}$ in Henle-407 cells and $2.0 \mathrm{~h}$ in J774.A1 cells, with no significant differences observed between the Salmonella strains (data not shown). Therefore, the Spv phenotype of increased intracellular growth could not be reproduced in vitro in cell culture, even though the $s p v$ genes are induced in these models.

\section{DISCUSSION}

\section{Induction of spvA during exponential growth in defined media}

A considerable amount of work has been done to examine the regulation of $s p v$ gene expression (reviewed 
in Gulig et al., 1993; Guiney et al., 1995). A common theme among published results is the induction of the $s p v$ genes during the transition into post-exponential/ stationary-phase growth in rich media such as LB or by glucose limitation in minimal medium. Observing the constant exponential kinetics of net growth yields of S. typhimurium in spleens of BALB/c mice (Gulig \& Curtiss, 1987), we questioned whether salmonellae actually attain stationary phase during infection of the animal host. Furthermore, we reported that the spv genes most likely increase the replication rate of S. typhimurium within host cells of infected mice (Gulig \& Doyle, 1993). We therefore examined expression of $s p v$ genes in ISM, a cell-free medium designed to mimic the intracellular milieu (Headley \& Payne, 1990). spvA was greatly induced during exponential growth in ISM, as well as exponential growth in M9 minimal medium and stationary phase in LB. In fact, the level of expression of spvA during exponential growth in ISM was higher than that obtained at stationary phase in LB. $s p v$ gene expression could therefore be regulated by composition of the growth medium as well as cessation of growth. When Valone et al. (1993) examined the expression of $\mathrm{Spv}$ proteins expressed from the virulence plasmid of $S$. dublin, spv genes were induced by environmental stimuli such as glucose limitation, iron limitation and changes in $\mathrm{pH}$. Addition of $0.05 \%$ glucose to their medium inhibited Spv expression until the postexponential phase of growth. However, we found that $s p v A$ is induced in exponential-phase growth in the presence of relatively high amounts of glucose, with ninefold higher induction in ISM containing $0.4 \%$ glucose than in M9 minimal medium containing $0.2 \%$ glucose. The differences in $s p v$ expression between our studies and those of Valone et al. (1993) may be due to using different media or examining mRNA versus protein expression. However, by using Western blotting to measure expression of Spv proteins, we detected similar patterns of induction of SpvC at exponential phase in ISM and at stationary phase in LB reported here for mRNA (data not shown). Finally, our differences with Valone et al. (1993) might be explained by the report that regulation of $s p v$ genes in $S$. dublin is different from S. typhimurium (Taira et al., 1995). Most recently, El-Gedaily et al. (1997) reported that certain short chain fatty acids added to LB could induce $s p v$ gene expression in S. dublin during exponential growth. Their results confirm that salmonellae can induce $s p v$ gene expression in the absence of cessation of growth; however, it is difficult to compare their results to ours since ISM and M9 do not contain short-chain fatty acids and El-Gedaily et al. (1997) did not examine effects of short-chain fatty acids in minimal medium.

Our initial experiments involved direct measurement of RNA expressed from the wild-type $s p v$ genes encoded on the native virulence plasmid of $S$. typhimurium, as opposed to the use of lac $Z$ operon or gene fusions encoded on recombinant plasmids in trans to the virulence plasmid or fusions recombined into the $s p v$ genes. Our approach therefore eliminates complications of copy number of fusion-containing recombinant plasmids, interruption of the $s p v$ genes, disruption of the stoichiometry in the positive regulator SpvR to the $s p v A B C D$ operon, altered stability of $s p v$ mRNA brought on by differences in the primary transcripts encoding fusions and stability of the $\beta$-galactosidase protein as an end point for gene expression. Although the results for induction of $s p v A$ were qualitatively similar using RNase protection analysis and lacZ fusions, the quantitative aspects of induction were different with the two procedures. For example, the induction of $s p v A$ at exponential phase in ISM compared with LB as measured by RNase protection was 65 -fold compared with 16 -fold as measured by spvA-lacZ in trans to the virulence plasmid.

\section{Induction of spvA intracellularly in cell culture during exponential growth and in mice}

Having established that $s p v A$ could be induced in a growth medium mimicking the intracellular environment, we confirmed that the spv genes of S. typhimurium were rapidly induced intracellularly within infected mammalian cell culture in vitro, both phagocytes and non-phagocytes. Using a translational spvB-lacZ gene fusion in S. dublin, Fierer et al. (1993) also demonstrated that $S p v B$ is induced in a variety of tissue culture cells. More recently, Chen et al. (1996a) measured $s p v B$ expression from $S$. dublin in cultured J774 cells and T84 cells and reported as high as 600-fold induction. However, as discussed below and different from our results, the salmonellae apparently were not replicating in the infected cells. Rhen et al. (1993) demonstrated that the $S$. typhimurium spvR and $s p v A$ genes are transcriptionally induced $12 \mathrm{~h}$, but not $4 \mathrm{~h}$, after infection of J774.A1 macrophage-like cells. It is noteworthy that their reporter system was based on fusing $s p v A$ and $s p v R$ sequences with the E. coli KS71A fimbrial gene cluster and measuring the percentage of fimbriated bacteria using immunofluorescence microscopy.

Having confirmed that $s p v$ gene expression was induced within cultured mammalian cells, we examined expression of $s p v A-l a c Z$ intracellularly and extracellularly in vivo in infected mice. By $4 \mathrm{~h}$ post-inoculation, spvA had been specifically induced 70 -fold by intracellular salmonellae relative to the input LB-grown bacteria. Therefore, the $s p v$ genes are rapidly induced within host cells in vivo to a greater degree than we observed in vitro. Extracellular salmonellae in peritoneal cavities were not induced for $s p v$ expression, consistent with the lack of induction in serum in vitro and extracellularly in cell culture in vitro, as well as a lack of function for the $s p v$ genes extracellularly in vivo (Gulig \& Doyle, 1993). Our demonstration of in vivo induction of $s p v A$ agrees with the recent results of Heithoff et al. (1997), who used in vivo expression technology to show that $s p v B$ was expressed by $S$. typhimurium in spleens of infected mice. However, we have extended their data to show that induction of $s p v$ genes only occurs intracellularly. Therefore, the salmonellae appear to be able to sense the intracellular environment of animal cells and respond by 
inducing the $s p v$ genes, which are essential for sustaining systemic infection in the host.

Since we determined that $s p v$ gene expression could be highly induced during exponential-phase growth in ISM and within cultured mammalian cells, we examined the growth state of the salmonellae which had induced $s p v$ gene expression within infected epithelial cells and macrophage-like cells. At the time of induction of $s p v A$, the salmonellae were replicating with a doubling time of $2-2.5 \mathrm{~h}$. There was no evidence of an extended lag phase upon infection and further induction of $s p v A$ continued as the bacteria replicated with exponential kinetics. As noted above, Chen et al. (1996a) found a considerably larger induction of $s p v B$ from $S$. dublin within cultured host cells, but this increase in expression occurred while the bacteria were apparently in a non-replicating phase intracellularly in the tissue culture cells. Abshire \& Neidhardt (1993) proposed that there were two populations of salmonellae within infected U937 macrophage-like cells, a minority rapidly growing population and a majority static population. It is therefore possible that intracellular induction of $s p v$ genes observed in our studies could be due to the putative static bacterial population. However, according to the data of Abshire \& Neidhardt (1993) and our calculations, the minority replicating population would have an intracellular generation time of approximately $1 \mathrm{~h}$, and this seems rapid for growth of salmonellae within a phagosome or phagolysosome. Unfortunately, technical limitations involving efficiency of recovering salmonellae from gentamicin-treated, infected peritoneal cavities precluded our determination of the intracellular growth rate of salmonellae while expressing $s p v A$ in peritoneal cavities of infected mice.

\section{Roles of SpvR and RpoS in regulation of spvA}

Since the physiological states of salmonellae growing exponentially in ISM and at stationary phase in LB are different, we examined the roles of the plasmid-encoded positive regulatory protein, $\mathrm{SpvR}$, and chromosomally encoded alternative $\sigma$ factor, RpoS, in ISM vs stationaryphase inductions of $s p v A$. Maximal expression of $s p v A$ at exponential phase in ISM and stationary phase in LB required both SpvR and RpoS. Induction of $s p v A$ under these two conditions was not dependent on differential promoter usage. Instead, we have found that regulation of $s p v A$ appears to be mediated primarily by controlling the expression of $s p v R$ (J. A. Wilson \& P. A. Gulig, unpublished data). In fact, we have found that ISM and stationary-phase inductions of $s p v R$ mRNA exhibit genetically separable phenotypes. The RpoS-dependent induction of $s p v$ gene expression during exponential growth in ISM initially seemed like a paradox, since this $\sigma$ factor was originally described primarily in relation to starvation or stationary phase (Groat et al., 1986; Jenkins et al., 1988; Bohannon et al., 1991; HenggeAronis et al., 1991; Lange \& Hengge-Aronis, 1991; McCann et al., 1991). However, it has become evident that levels of RpoS can be increased by heat shock and osmotic shock (Hengge-Aronis, 1996; Muffler et al.,
1997; Jishage et al., 1996). The short chain fatty acid induction of $s p v$ expression in S. dublin during exponential growth in LB is also dependent on RpoS (ElGedaily et al., 1997). Therefore, RpoS is capable of being involved in induction of gene expression under certain conditions during exponential growth. It is not known how induction of $s p v A$ gene expression during exponential growth in ISM fits into these patterns.

\section{Conclusions}

In summary, the studies described here demonstrate that the virulence-plasmid-encoded $s p v$ genes can be induced while the salmonellae are replicating with rapid kinetics ( $1.2 \mathrm{~h}$ doubling time) in ISM. Furthermore, when the $s p v$ genes are induced within infected tissue culture cells in vitro, the bacteria are replicating exponentially with a doubling time of $2-2.5 \mathrm{~h}$. Regulation of induction of $s p v A$ in ISM was dependent on both SpvR and RpoS, which are also essential for the stationary-phase induction of the spv genes. Therefore, although much emphasis has been placed on the stationary-phase induction of the $s p v$ genes, it is possible that more relevant aspects of genetic regulation are involved in the expression of the Salmonella spv genes during exponential growth of salmonellae within host cells.

\section{ACKNOWLEDGEMENTS}

This work was supported by NIH grant AI24821, American Heart Association-Florida Affiliate grants 89GIA81 and 92GIA868 to P.A.G., who is an American Heart Association Established Investigator with funds contributed in part by the American Heart Association - Florida Affiliate. J.A. W. was an American Heart Association - Florida Affiliate Graduate Fellow (92GSF/3). We thank Anuradha Menon for her help with experiments and Jeffrey Hillman and Carleen Collins for reviewing this manuscript. We thank Dr Katherine HammettStabler of the Shands Hospital Clinical Chemistry Laboratory for measuring the osmolalities of growth media.

\section{REFERENCES}

Abe, A., Matsui, H., Danbara, H., Tanaka, K., Takahashi, H. \& Kawahara, K. (1994). Regulation of $s p v R$ gene expression of Salmonella virulence plasmid pKDSC50 in Salmonella choleraesuis serovar choleraesuis. Mol Microbiol 12, 779-787.

Abshire, K. Z. \& Neidhardt, F. C. (1993). Growth rate paradox of Salmonella typhimurium within host macrophages. J Bacteriol 175, 3744-3748.

Ausubel, F. M., Brent, R., Kingston, R. E., Moore, D. D., Seidman, J. G., Smith, J. A. \& Struhl, K. (1993). Current Protocols in Molecular Biology. New York: Wiley Interscience.

Bohannon, D. E., Connell, N., Keener, J., Tormo, A., EspinosaUrgel, M., Mercedes Zambrano, M. \& Kolter, R. (1991). Stationaryphase-inducible 'gearbox' promoters: differential effects of katF mutations and role of $\sigma^{70}$. J Bacteriol 173, 4482-4492.

Caldwell, A. L. \& Gulig, P. A. (1991). The Salmonella typhimurium virulence plasmid encodes a positive regulator of a plasmidencoded virulence gene. J Bacteriol 173, 7176-7185.

Chen, C. Y., Buchmeier, N. A., Libby, S., Fang, F. C., Krause, M. \& Guiney, D. G. (1995). Central regulatory role for the RpoS sigma 
factor in expression of Salmonella dublin plasmid virulence genes. J Bacteriol 177, 5303-5309.

Chen, C. Y., Eckmann, L., Libby, S. J., Fang, F. C., Okamoto, S., Kagnoff, M. F., Fierer, J. \& Guiney, D. G. (1996a). Expression of Salmonella typhimurium rpoS and rpoS-dependent genes in the intracellular environment of eukarytotic cells. Infect Immun 64, $4739-4743$.

Chen, L. M., Kaniga, K. \& Galan, J. E. (1996b). Salmonella spp. are cytotoxic for cultured macrophages. Mol Microbiol 21, 1101-1115.

Coynault, C., Robbe-Saule, V., Popoff, M. Y. \& Norel, F. (1992). Growth phase and SpvR regulation of transcription of Salmonella typhimurium spuABC virulence genes. Microb Pathog 13, 133-143.

Deretic, V., Gill, J. F. \& Chakrabarty, A. M. (1987). Gene algD coding for GDP mannose dehydrogenase is transcriptionally activated in mucoid Pseudomonas aeruginosa. J Bacteriol 169, 351-358.

Donnenberg, M. S. \& Kaper, J. B. (1991). Construction of an eae deletion mutant of enteropathogenic Escherichia coli by using a positive-selection suicide vector. Infect Immun 59, 4310-4317.

El-Gedaily, A., Paesold, G., Chen, C.-Y., Guiney, D. G. \& Krause, M. (1997). Plasmid virulence gene expression induced by short-chain fatty acids in Salmonella dublin: Identification of rpoS-dependent and rpoS-independent mechanisms. J Bacteriol 179, 1409-1412.

Errington, J. (1986). A general method for fusion of the Escherichia coli lacZ gene to chromosomal genes in Bacillus subtilis. J Gen Microbiol 132, 2953-2966.

Fang, F. C., Krause, M., Roudier, C., Fierer, J. \& Guiney, D. G. (1991). Growth regulation of a Salmonella plasmid gene essential for virulence. J Bacteriol 173, 6783-6789.

Fang, F. C., Libby, S. J., Buchmeier, N. A., Loewen, P. C., Switala, J., Harwood, J. \& Guiney, D. G. (1992). The alternative sigma factor KatF (RpoS) regulates Salmonella virulence. Proc Natl Acad Sci USA 89, 11978-11982.

Fierer, J., Krause, M., Tauxe, R. \& Guiney, D. (1992). Salmonella typhimurium bacteremia : association with the virulence plasmid. J Infect Dis 166, 639-642.

Fierer, J., Eckmann, L., Fang, F., Pfeifer, C., Finlay, B. B. \& Guiney, D. (1993). Expression of the Salmonella virulence plasmid gene $s p v B$ in cultured macrophages and nonphagocytic cells. Infect Immun 61, 5231-5236.

Finlay, B. B. \& Falkow, S. (1988). Comparison of the invasion strategies used by Salmonella cholerae-suis, Shigella flexneri, and Yersinia enterocolitica to enter cultured animal cells: endosome acidification is not required for bacterial invasion or intracellular replication. Biochimie 70, 1089-1099.

Finlay, B. B. \& Falkow, S. (1989). Common themes in microbial pathogenesis. Microbiol Rev 53, 210-230.

Fleming, T. J., Fleming, M. L. \& Malek, T. R. (1993). Selective expression of $\mathrm{Ly}-6 \mathrm{G}$ on myeloid lineage cells in mouse bone marrow. RB6-8C5 mAb to granulocyte-differentiation antigen (Gr-1) detects members of the Ly-6 family. I Immunol 151, 2399-2408.

Groat, R. G., Schultz, J. E., Zychlinsky, E., Bockman, A. \& Matin, A. (1986). Starvation proteins in Escherichia coli: kinetics of synthesis and role in starvation survival. J Bacteriol 168, 486-493.

Guiney, D. G., Libby, S., Fang, F. C., Krause, M. \& Fierer, J. (1995). Growth-phase regulation of plasmid virulence genes in Salmonella. Trends Microbiol 3, 275-279.

Gulig, P. A. \& Curtiss, R., III (1987). Plasmid-associated virulence of Salmonella typhimurium. Infect Immun 55, 2891-2901.
Gulig, P. A. \& Doyle, T. J. (1993). The Salmonella typhimurium virulence plasmid increases the growth rate of salmonellae in mice. Infect Immun 61, 504-511.

Gulig, P. A., Caldwell, A. L. \& Chiodo, V. A. (1992). Identification, genetic analysis, and DNA sequence of a $7 \cdot 8$-kilobase virulence region of the Salmonella typhimurium virulence plasmid. Mol Microbiol 6, 1395-1411.

Gulig, P. A., Danbara, H., Guiney, D. G., Lax, A. J., Norel, F. \& Rhen, M. (1993). Molecular analysis of virulence genes of the salmonella virulence plasmids. Mol Microbiol 7, 825-830.

Gutierrez, C., Barondess, J., Manoil, C. \& Beckwith, J. (1987). The use of transposon $\operatorname{Tn} p h o A$ to detect genes for cell envelope proteins subject to a common regulatory stimulus. Analysis of osmotically regulated genes in Escherichia coli. J Mol Biol 195, 289-297.

Headley, V. L. \& Payne, S. M. (1990). Differential protein expression by Shigella flexneri in intracellular and extracellular environments. Proc Natl Acad Sci USA 87, 4179-4183.

Heiskanen, P., Taira, S. \& Rhen, M. (1994). Role of $r p o S$ in the regulation of Salmonella plasmid virulence $(s p v)$ genes. FEMS Microbiol Lett 123, 125-130.

Heithoff, D. M., Conner, C. P., Hanna, P. C., Julio, S. M., Hentschel, U. \& Mahan, M. J. (1997). Bacterial infection as assessed by in vivo gene expression. Proc Natl Acad Sci USA 94, 934-939.

Hengge-Aronis, R. (1996). Back to log phase: $\sigma^{\mathrm{s}}$ as a global regulator in the osmotic control of gene expression in Escherichia coli. Mol Microbiol 21, 887-893.

Hengge-Aronis, R., Klein, W., Lange, R., Rimmele, M. \& Boos, W. (1991). Trehalose synthesis genes are controlled by the putative sigma factor encoded by $r p o S$ and are involved in stationaryphase thermotolerance in Escherichia coli. J Bacteriol 173, 7918-7924.

Jenkins, D. E., Schultz, J. E. \& Matin, A. (1988). Starvation-induced cross-protection against heat or $\mathrm{H}_{2} \mathrm{O}_{2}$ challenge in Escherichia coli. J Bacteriol 170, 3910-3914.

Jishage, M., Iwata, A., Ueda, S. \& Ishihama, A. (1996). Regulation of RNA polymerase sigma subunit synthesis in Escherichia coli: intracellular levels of four species of sigma subunit under various growth conditions. J Bacteriol 178, 5447-5451.

Kowarz, L., Coynault, C., Robbe Saule, V. \& Norel, F. (1994). The Salmonella typhimurium katF ( $r p o S)$ gene: cloning, nucleotide sequence, and regulation of $s p v R$ and $s p v A B C D$ virulence plasmid genes. J Bacteriol 176, 6852-6860.

Krause, M., Fang, F. C. \& Guiney, D. G. (1992). Regulation of plasmid virulence gene expression in Salmonella dublin involves an unusual operon structure. J Bacteriol 174, 4482-4489.

Lange, R. \& Hengge-Aronis, R. (1991). Growth phase-regulated expression of bolA and morphology of stationary-phase Escherichia coli cells are controlled by the novel sigma factor sigma S. J Bacteriol 173, 4474-4481.

Lennox, E. S. (1955). Transduction of linked genetic characters of the host by bacteriophage P1. Virology 1, 190-206.

McCann, M. P., Kidwell, J. P. \& Matin, A. (1991). The putative sigma factor KatF has a central role in development of starvationmediated general resistance in Escherichia coli. J Bacteriol 173, 4188-4194.

McKnight, A. J., Macfarlane, A. J., Dri, P., Turley, L., Willis, A. C. \& Gordon, S. (1996). Molecular cloning of F4/80, a murine macrophage-restricted cell surface glycoprotein with homology to the G-protein-linked transmembrane 7 hormone receptor family. J Biol Chem 271, 486-489. 
Maniatis, T., Fritsch, E. F. \& Sambrook, J. (1982). Molecular Cloning: a Laboratory Manual. Cold Spring Harbor, NY: Cold Spring Harbor Laboratory.

Matsui, H., Abe, A., Kawahara, K., Terakado, N. \& Danbara, H. (1991). Positive regulator for the expression of $M$ ba protein of the virulence plasmid, pKDSC50, of Salmonella choleraesuis. Microb Pathog 10, 459-464.

Matsui, H., Abe, A., Suzuki, S., Kijima, M., Tamura, Y., Nakamura, M., Kawahara, K. \& Danbara, H. (1993). Molecular mechanism of the regulation of expression of plasmid-encoded mouse bacteremia $(m b a)$ genes in Salmonella serovar choleraesuis. Mol Gen Genet 236, 219-226.

Miller, J. H. (1972). Experiments in Molecular Genetics. Cold Spring Harbor, NY: Cold Spring Harbor Laboratory.

Monack, D. M., Raupach, B., Hromockyj, A. E. \& Falkow, S. (1996). Salmonella typhimurium invasion induces apoptosis in infected macrophages. Proc Natl Acad Sci USA 93, 9833-9838.

Montenegro, M. A., Morelli, G. \& Helmuth, R. (1991). Heteroduplex analysis of Salmonella virulence plasmids and their prevalence in isolates of defined sources. Microb Pathog 11, 391-397.

Muffler, A., Barth, M., Marchall, C. \& Hengge-Aronis, R. (1997). Heat shock regulation of $\sigma^{5}$ turnover: a role for DnaK and relationship between stress responses mediated by $\sigma^{\mathrm{s}}$ and $\sigma^{32}$ in Escherichia coli. J Bacteriol 179, 445-452.

Norel, F., Robbe Saule, V., Popoff, M. Y. \& Coynault, C. (1992). The putative sigma factor KatF (RpoS) is required for the transcription of the Salmonella typhimurium virulence gene $s p v B$ in Escherichia coli. FEMS Microbiol Lett 78, 271-276.

O'Byrne, C. P. \& Dorman, C. J. (1994a). The $s p v$ virulence operon of Salmonella typhimurium LT2 is regulated negatively by the cyclic AMP (cAMP)-cAMP receptor protein system. J Bacteriol 176, 905-912.

O'Byrne, C. P. \& Dorman, C. J. (1994b). Transcription of the Salmonella typhimurium spv virulence locus is regulated negatively by the nucleoid-associated protein H-NS. FEMS Microbiol Lett 121, 99-105.

O’Neal, C. R., Gabriel, W. M., Turk, A. K., Libby, S. J., Fang, F. C. \& Spector, M. P. (1994). RpoS is necessary for both the positive and negative regulation of starvation survival genes during phosphate, carbon, and nitrogen starvation in Salmonella typhimurium. J Bacteriol 176, 4610-4616.
Pollack, C., Straley, S. C. \& Klempner, M. S. (1986). Probing the phagolysosomal environment of human macrophages with a $\mathrm{Ca}^{2+}$-responsive operon fusion in Yersinia pestis. Nature 322, 834-836.

Rhen, M., Riikonen, P. \& Taira, S. (1993). Transcriptional regulation of Salmonella enterica virulence plasmid genes in cultured macrophages. Mol Microbiol 10, 45-56.

Riikonen, P., Makela, P. H., Saarilahti, H., Sukupolvi, S., Taira, S. \& Rhen, M. (1992). The virulence plasmid does not contribute to growth of Salmonella in cultured murine macrophages. Microb Pathog 13, 281-291.

Rogers, J. A., Matsui, H. \& Gulig, P. A. (1995). spvA of the Salmonella typhimurium virulence plasmid can act as a transcriptional repressor of $s p v R$ and is not essential for virulence in orally inoculated mice. Abstr 95th Annu Meet Am Soc Microbiol B304.

Schmeiger, H. (1972). Phage P22-mutants with increased or decreased transduction abilities. Mol Gen Genet 119, 75-88.

Spink, J. M., Pullinger, G. D., Wood, M. W. \& Lax, A. J. (1994). Regulation of $s p v R$, the positive regulatory gene of Salmonella plasmid virulence genes. FEMS Microbiol Lett 116, 113-121.

Taira, S., Riikonen, P., Saarilahti, H., Sukupolvi, S. \& Rhen, M. (1991). The $m k a C$ virulence gene of the Salmonella serovar typhimurium $96 \mathrm{~kb}$ plasmid encodes a transcriptional activator. Mol Gen Genet 228, 381-384.

Taira, S., Heiskanen, P., Hurme, R., Heikkila, H., Riikonen, P. \& Rhen, M. (1995). Evidence for functional polymorphism of the $s p \nu R$ gene regulating virulence gene expression in Salmonella. Mol Gen Genet 246, 437-444.

Valone, S. E., Chikami, G. K. \& Miller, V. L. (1993). Stress induction of the virulence proteins (SpvA, -B, and -C) from native plasmid pSDL2 of Salmonella dublin. Infect Immun 61, 705-713.

Wilkins, E. G. L. \& Roberts, C. (1988). Extraintestinal salmonellosis. Epidemiol Infect 100, 361-368.

Yanisch-Perron, C., Vieira, J. \& Messing, J. (1985). Improved M13 phage cloning vectors and host strains: nucleotide sequences of the M13mp18 and pUC19 vectors. Gene 33, 103-119.

Received 29 May 1997; revised 13 August 1997; accepted 20 August 1997. 